\title{
Corpus-driven Lexical Profiles of the Turkish Synonym Set Sadece, Yalnızca and Yalnız
}

\author{
Muhammet Fatih Adigüzel \\ ORCID ID: 0000-0002-6962-0078 \\ Mersin Mehmet Akif Ersoy Sosyal Bilimler Lisesi, Afet Evler Mah. 31112 Sok. No.1 \\ Yenişehir/Mersin \\ mfatihad@gmail.com
}

(Received 3 September 2018; accepted 15 May 2019)

\begin{abstract}
This is a corpus-driven study based on the TNCv3.0 to identify lexical profiles of the synonym set of Turkish exclusive adverbials sadece, yalnizca and yalniz within the framework of the Model of Extended Lexical Units (Stubbs, 2002). From the concordances of the adverbials, their contextdependent semantic, pragmatic and syntactic properties, co-occurrence tendencies, and synonymity levels were identified. It was found that sadece and yalnizca have a high contextual and collocational equinormality and are completely intersubstitutable and complete synonyms (Lyons, 1981) with yalnizca used less frequently. Yalniz is polysemous and multifunctional and has a sense synonymy relation with the others only when it means only. Even in the sense of only, yalniz was found to be rarely used in certain lexical bundles the other adverbials form. Yalnız was also found to have a topic shifter function. In contexts in which yalnz means only, the three adverbials are cognitive synonyms (Cruse, 1986).
\end{abstract}

Keywords: Turkish exclusive adverbials, corpus-driven, synonymy, lexical profiling, intersubstitutability

Türkçe Eşanlamlılar Seti Sadece, Yalnızca ve Yalnız’ın Derlem-çıkışı Sözcüksel Profilleri

ÖZ: Bu çalışma, Genişletilmişs Sözcükbirim Modeli (Stubbs, 2002) çerçevesinde Türkçedeki sınırlayıcı belirteçlerden olan sadece, yalnızca ve yalnız potansiyel eşanlamlılar setinin sözcük profillerini belirlemek için Türkçe Ulusal Derlemine (TNCv3.0) dayanan derlem çıkışlı bir çalışmadır. Belirteçlerin bağlı dizinlerinden, bağlam-bağımlı anlambilimsel, edimbilimsel ve sözdizimsel özellikleri, eşdizim eğilimleri, ve eş anlamlılık seviyeleri tespit edilmiştir. Araştırmada sadece ve yalnızcanın yüksek ölçüde bağlamsal ve eşdizimsel denkliğe sahip olduğu ve tamamen birbirleriyle değiştirilebilir olduğu ve Lyons'ın (1981) ölçütlerine göre yalnızcanın daha seyrek kullanılması dişında sadece ve yalnızcanın tam eşanlamlı oldukları görülmüştür. Yalnız sözcüğü ise birden çok anlama ve işleve sahip olup yalnızca sadece anlamındayken yalnızca ve sadece belirteçleriyle anlam eş anlamlılığı ilişkisine sahiptir. Yalnız sözcügünün, sadece anlamında bile, diğer iki belirtecin oluşturduğu kalıplaşmış sözcük örüntülerinde seyrek kullanıldığı saptanmıştır. Ayrıca yalnızın konu değiştirici işlevi olduğu da 
belirlenmiştir. Yalnızın sadece anlamına geldiği bağlamlarda üç belirtecin de bilişsel eşanlamlı (Cruse, 1986) olduğu anlaşılmıştır.

Anahtar sözcükler: Türkçe sınırlayıcı belirteçler, derlem çıkışlı, eşanlamlılık, sözcük profili çıkarma, birbiri yerine konulabilirlik

\section{Introduction}

Turkish exclusive adverbs sadece, yalnızca and yalnız are a potential synonym set for Turkish speakers, which are used interchangeably in certain contexts so as to focus on a part of their utterance exclusively. Göksel and Kerslake (2005:212) classify them as exclusive adverbials, which "restrict the applicability of what is being said to the focus constituent of a sentence." Sadece, which is the most frequently used and prototypical one, is derived with the addition of the suffix $-\mathrm{cA}$ to sade, which means pure or simple. Yalnizca is derived with the addition of the adverb generating suffix - cA to yalnız, which means alone, lonely, or but. Yalnız is often used as an adjective in the sense of alone or lonely but can replace sadece and yalnizca in certain contexts and when it does so, it functions as an adverb meaning only.

This research article adopts a corpus-driven approach, aiming to unearth semantic and pragmatic facts about the potential synonym set sadece, yalnizca and yalnız. Through concordance analyses, we aim to demonstrate by means of a lexical profile study how intersubstitutable these words are. Contextdependent meanings and functions of the items, their collocational and colligational features are explored and compared. Some typical collocational patterns in which any of these focus adverbs co-occur recurrently to form lexical bundles are separately discussed.

One of the main benefits of concordance lines is that they help us interpret "the meaning and behaviour of individual lexical items, and the pragmatic meaning of given phrases" (Hunston (2002:39). Hunston (2002:48) also states that "words with similar meanings tend to share patterns". A corpus sheds light on contextual representations of lexical items, which is defined by Miller and Charles (1991:26 cited in Gries and Otani, 2010:142) as "a mental representation of the contexts in which the word occurs, a representation that includes all of the syntactic, semantic, pragmatic, and stylistic information required to use the word appropriately." It is for this reason that we not only checked the corpus TNCv3.0 for any distinct senses of sadece, yalnizca and yalnız, but also focused on their collocational patterns and phraseologies. We not only searched for semantic and pragmatic similarities / dissimilarities but also collocational overlaps as indicative of their intersubstitutability.

In the next section, theoretical framework for the research article is covered. To this end, a brief discussion of synonymity and a somewhat detailed corpusdriven lexical profiling through the Model of Extended Lexical Unit (Sinclair, 
1991, 1996/2004, 1998 and Stubbs, 2002) are explicated. As constituents of this model, collocation, colligation, semantic preference and semantic prosody are described so that novices at this profiling model corpus linguistics become familiar with it.

\section{Theoretical Framework}

\subsection{Synonymy}

It is a fact that words are polysemous and it is often the case that one sense of a word is synonymous with a particular sense of another word. Therefore, synonymy is often partial. In the following statement the Turkish focus adverbs sadece, yalnızca and yalnız are intersubstitutable and can be judged as synonymous:

(1) Sadece / yalnızca / yalnız John seni seviyor. (Only John likes you)

On the other hand, the three words are not interchangeable in the following example:

(2) Benimle gelebilirsin; *sadece / *yalnızca / yalnız bana karışmayacaksın. (You can come with me, but you mustn't interfere with me)

In the second example, yalnız functions as a conjunctive like ama (but), followed by a requirement imposed upon the addressee and therefore cannot be substituted for by sadece or yalnizca. They have neither semantic nor pragmatic equinormality in this case.

Cruse (1986:267) defines synonyms stating "synonyms, then, are lexical items whose senses are identical in respect of 'central' semantic traits, but differ, if at all, only in respect of what we may provisionally describe as 'minor' or 'peripheral' traits...". It is a common argument that no two words in a natural language can be absolutely synonymous because absolute synonymy involves the interchangeability and equinormality of the words in a synonym set in all their possible contexts (Cruse, 1986:268). This is quite a rare phenomenon and there are certainly differences, either small or big, between the target items; therefore, many linguists tend to refer to them as "near synonyms" (Aksan, D., 1972, Aksan, Y., 2011; Aksan et al., 2008; Edmonds and Hirst, 2002; Vardar, 1998 and Ersoylu, 2011 to cite a few). However, what they mean by "near synonyms" is that no two words can be absolutely synonymous and should not be confused with the "near synonymy" in Cruse's (1985) classification of synonymy. According to Cruse, in near synonyms denotational meanings are similar (e.g. foggy/misty) but they are not mutually entailing (if the weather is foggy, it is not necessarily misty), while in cognitive 
synonymy the relevant senses of the items in the synonym set have the same denotational value (die/pass away) and are mutually entailing (if someone has died, he/she has passed away or vice versa).

Stanojević (2009:194) claims that what most linguists regards as synonymy is cognitive synonymy. It involves cases in which one or more senses of the lexical items in a synonym set have the same propositional, denotational or referential meaning (the items are mutually entailing), but differ in associative meaning (connotational, emotional, expressive, evaluative-speaker attitude, prosody) depending on the context (Cruse, 1986; Murphy, 2003; Edmonds and Hirst, 2002; Cruse, 2000 and Doğan, 2011). Stanojević (2009:198-199) mentions collocational, stylistic, register and dialectal differences concerning cognitive synonyms. Edmonds and Hirst (2002) classify possible differences between potential synonym sets as expressive (reflecting the speaker's attitude/prosody), collocational (selectional restrictions) and syntactic ones (colligational features).

To sum up, synonymity, understood this way, is a context-dependent, pragmatic phenomenon (Murphy, 2003:133). Judging by the fact that certain semantic and pragmatic differences are expected between sadece, yalnizca and yalnız, a corpus-driven lexical profiling research will provide indispensable insights as it is based on attested, corpus data. We compared lexical profiles of these items in concordance data to "decide in what circumstances substitution of one item for another is possible in a text" (Partington 1998:29).

\subsection{Lexical Profiling}

Lexical profiling involves teasing out from a corpus the usual collocates, colligates, semantic preference and semantic/discourse prosody of a lexical item to unearth 'extended units of meaning' surrounding the item (Sinclair, 1996/2004). Sinclair thinks that words are not independent carriers or containers of units of meaning; on the contrary, units of meaning are created in utterances with the contribution of more than one word co-selected. Sinclair (2004:20) contends that "the meaning of words together is different from their independent meanings." Thus certain words collocate with others to produce combinatorial meanings as part of a phraseological tendency. Sinclair (2000:197) draws attention to lexical priming - a mind internal phenomenon which explains his conclusion that "a large proportion of the word occurrence is the result of co-selection - that is to say, more than one word is selected in a single choice."

Lexical profiling is a strenuous undertaking to present a comprehensive coverage of the characteristic uses of a node (a lexical item or phrase being examined through concordancing, Stubbs, 2002). Concordance lines of a node provide many contextual examples that indicate what meaningful relations 
words enter into with other words in their lexical environments. Such corpus data gives us "paradigmatic and syntagmatic dimensions of choice" about a lexical item/node (Sinclair, 1998:14). Sinclair's works (1991, 1996, 1998) focusing on a re-description of the lexical item based on corpus data in terms of its co-selectional properties led to Stubbs (2002) developing the Model of Extended Lexical Units. This lexical profiling model involves "successive analysis of collocations, colligations, semantic preferences and discourse (semantic) prosodies" of a lexical item through concordance analysis (McEnery and Hardie, 2012:132). We employed this model to work on our potential synonym set of Turkish exclusive adverbials sadece, yalnizca and yalniz. Explications about the constituents of the model are given below.

\subsubsection{Collocation}

Collocation is a main organizing feature of texts. McEnery and Hardie (2012:123) use this term "to refer to a wide range of different co-occurrence patterns that may be extracted from a corpus." It is a co-occurrence pattern between two items that exist in close proximity to each other even though the items may not be adjacent. If an item habitually comes after or before another item more often than would be by chance, there is a collocational pattern and one is the collocate of the other. The item whose total pattern of co-occurrence with other words is under examination is called a node and a collocate is any of the items which occur with the node in its lexical environment (Sinclair et al 2004, cited in McEnery and Hardie 2012:124).

Some words just happen to be together on the basis of 'open choice principle' (Sinclair, 1996/2004). In such cases we observe lexical items that only co-occur. Some collocation patterns display established lexical partnerships or phraseologies which are called lexical phrases, lexical bundles or prefabricated routines (Hunston 2002:138). These suggest 'idiom principle' (Sinclair, 1996/2004). Word occurrences are therefore on a continuum between 'open choice' and 'idiomatic expressions'. A node's collocational patterns usually display distinct behaviours and semantic or pragmatic meanings. Collocates contribute to the manifestation of the potential of the word in creating certain units of combinatorial or collocative meaning with them (Leech, 1985; Firth, 1957). Hence, collocation is not simply a juxtaposition of words. Rather, it is an order of mutual expectancy to create certain meanings or functions (Stewart 2010:85). 


\subsubsection{Colligation}

Colligation is similar to collocation except that we focus on the node's habitual co-occurrence with words or phrases which denote grammatical categories (Baker, Hardier \& McEnery, 2006:36). For instance, in English nouns usually colligate with "the" or adjectives and adjectives with degree adverbs or prepositions.

\subsubsection{Semantic Preference}

Partington (2004:145) refers to semantic preference as the relationship between a lemma and a set of semantically related words. Semantic preference is about the collocational behaviour of a lexical item - what semantic set of words that it habitually co-occurs with. Similarly, Bednarek (2008:120) points out that semantic preference is related to a lexical item's habitual co-occurrence with words or phrases which share a semantic feature or belong to certain semantic fields. To determine semantic preferences of a lexical item, the first step is to unearth the salient collocates from its concordance lines either by hand and eye method or via significance tools of the corpus software. Subsequently, the linguist assigns labels for semantic domains of the item's usual collocates. For a well-known example, in his work on "the naked eye", Sinclair (2004) demonstrated that this phrase has a semantic preference for "visibility."

\subsubsection{Semantic/Discourse Prosody}

Semantic prosody is the most abstract and important constituent of lexical profiling through the Model of Extended Lexical Units. Louw (2000:57) provides a most recent working definition of semantic prosody: "[A] semantic prosody refers to a form of meaning which is established through the proximity of a consistent series of collocates, often postulated as positive or negative, and whose primary function is the expression of the attitude of its speaker or writer towards some pragmatic situation." Sinclair also emphasizes the pragmatic side of semantic prosody which suggests speaker meaning. He states that "a semantic prosody is attitudinal, and on the pragmatic side of the semantics/pragmatics continuum" (Sinclair, 2004:34).

Sinclair (2004) argues that semantic prosody is relevant to pragmatics; that is, speaker's intended meaning is the key factor. Thus the normal semantic values of lexical items are not necessarily relevant. Semantic prosody provides a link between the node in question and its lexical environment. "It expresses something close to the "function' of the item." In his identification of the semantic prosody of the lexical unit the naked eye, Sinclair postulates a prosody of difficulty. He bases this identification upon the item's lexical environment what words "naked eye" semantically prefers: see, visible, invisible, faint, 
weak, small, and difficult. His assignment of the prosody of difficulty for the naked eye demonstrates that semantic prosodies are not always labelled as favourable/unfavourable or positive/negative.

Both Sinclair (2004) and Stubbs (2002) think that the semantic prosody of a lexical item reflects the pragmatic motivation or reason for which it is chosen for an utterance. This leads to the conclusion that distinct semantic/discourse prosody of lexical items is quite relevant to the choice of a near synonym in a set rather than another in an utterance. Murphy (2003:162) points out that "when a synonym is introduced into discourse, especially if that synonym is a less common member of the synonymy set, the listener assumes that there is a reason for the speaker's choice of that synonymy rather than another possibility."

\section{Data and Method}

This is a corpus-driven study (Tognini-Bonelli, 2001) of lexical profiling to determine the semantics and pragmatics of the Turkish exclusive adverbials sadece, yalnizca and yalnız, which are used synonymously in certain contexts. The concordance lines were obtained from the Turkish National Corpus [TNCv3.0 (http://v3.tnc.org.tr)]. The corpus, which is composed of 50 million words, is a balanced one which is representative of Turkish and as yet is the first and most important reference corpus of Turkish.

The present study employs a corpus driven approach, - an inductive process in which the corpus is explored "to uncover new grounds, posit new hypotheses and not always support old ones" (Tognini-Bonelli, 2001:65). "The general methodical path is clear: observation leads to hypothesis leads to generalisation leads to unification in theoretical statement" (ibid:66). As can be understood from the Findings section, our first step was to make an overall analysis of the semantic and pragmatic features of our synonym set sadece, yalnizca and yalnız. To this end, their concordances were obtained from TNCv3.0 and analysed in a cyclical manner until no new discernible patterns, meanings and functions are left that can be associated with the exclusive adverbials. The process of our observation of the concordance lines of each node to postulate hypotheses is similar to Sinclair's (2003) seven-step procedure, namely 1) Initiate 2) Interpret 3) Consolidate 4) Report 5) Recycle 6) Result and 7) Repeat. This is not a single linear process but a cyclical one, repeated over and over to reach new findings until no discernible patterns, meanings and functions are left. About 250 concordance lines were examined for each node to postulate our hypotheses about the node's general semantic and pragmatic features.

The second main step of our work is to evaluate each word in our potential synonym set on the basis of Stubbs' (2002) the Model of Extended Lexical 
Units, which involves "successive analysis of collocations, colligations, semantic preferences and discourse (semantic) prosodies" of a lexical item through concordance analysis (McEnery and Hardie, 2012:132). To determine each node's top collocates, the technique of concordance via significance (McEnery \& Hardie, 2012:127) was used with a -2+2 span. The top 15 cooccurences of sadece and yalnizca can be seen at the end of the study (Appendix 1 and 2). Because yalnız is polysemous and multifunctional and has a synonymy relationship only when it means only, its collocates and colligates displayed a noisy concordance. Therefore, it was analysed separately. Some of the top collocates of sadece and yalnızca were in fact grammatical collocates colligates. Some top co-occurrence patterns were found to have formed lexical bundles or multi-word units which are co-selected to serve some pragmatic functions. To determine the speaker intents (pragmatic concerns) underlying the lexical bundles (e.g. ben sadece/yalnızca, ise sadece/yalnız...etc), all such examples were extracted from the corpus and analysed separately.

To determine semantic preferences and prosodies as part of lexical profiling through the Model of Extended Lexical Units proved to be meaningless because sadece, yalnızca and yalnız as exclusive adverbials do not have selectional restrictions from which to make abstractions. However, when these words form lexical bundles or multi-word units like "ben sadece," they were observed to have certain discourse prosodies. As a final step, all our findings about the lexical profiles of sadece, yalnızca and yalnız were analysed to demonstrate their levels of synonymity on the basis of classifications of Lyons (1981), Cruse (1986) and Murphy (2003).

\section{Findings}

\subsection{Corpus-driven Overall Analysis of Sadece and Yalnızca}

The exclusive adverbial sadece occurs 40543 times in the corpus (TNCv3.0), while its nearest synonym yalnizca occurs 13492, almost three times as infrequently. As the most commonly used one in our synonym set, sadece is the prototypical focus adverb in Turkish which corresponds to English only or just. About 250 hundred concordance lines for each of sadece and yalnizca were analysed in a cyclical way until no distinct discernible uses or functions were left.

From the attested examples it is observed that sadece and yalnizca share the same sense and function as the English only. Like only, they are most often placed before the phrase or clause that they modify. Although these exclusive adverbs colligate with various phrases or clauses, the vast majority, nearly three quarters, of the sentential constituents modified by them are nominal phrases or clauses. In Turkish the nominals often have case endings (nominative, genitive, 
possessive, locative, accusative, dative, instrumental or ablative suffixes), some of which correspond to multi-word prepositional phrases in English.

(3) ....sadece medya sektörüne hizmet veren ..... (NP with dative case) [.... which provides service only to the Media sector....] (W-MF25D1B2156-6)

(4) Ayrıca bu sorunlar sadece iç nedenlerden değil, dış nedenlerden de kaynaklaniyordu. (NP with ablative case) [Besides these problems resulted not only from domestic (reasons) but also external reasons] (W-MD02A2A3324-1)

(5) ....yorumlama ve uygulamayı gözardı edip sadece işlem becerilerini geliștirmeyi amaçlarlar. (infinitival nominal with accusative case) [(They) ...diregard commenting and practice but aim only to improve processing skills] (W-MD39E1B-3360-1)

(6) Saygınlık ona göre yalnızca doktor olmakla sağlanabiliyor. (nominal phrase with instrumental case) [According to him, prestige can be achieved only by becoming a doctor] (W-MA16B2A-1950-4)

(7) ...bu mumların yalnızca kendi odasında yanmasına izin verir. (nominal phrase with locative case) [...she/he allows these candles to burn only in her/his own room] (W-MA16B3A-0655-1)

Like their match (only) in English, sadece and yalnızca modify other parts of speech, phrases or clauses in Turkish, although we encountered fewer examples compared to nominal phrases or clauses.

(8) ....her şeyi halleden oydu. Ben sadece anlaşmaya imza atıyor, film çekimlerine_gidiyordum. (Whole verb predicate is modified) [It was he/she who arranged everything. I just signed the contract and went to the film shots = What I only did was to sign the contract and go to the film shots] (W-MG09C3A-0355-2)

(9) Kültürümüz yalnızca bize mi ait? (Pronoun bize is modified) [Does our culture belong only to $u s$ ?] (W-MF10A1A-1824-1)

(10) Sadece Dide'yle tanıștıktan sonra, flüt sesini duymaya başladığımı hatırliyordum. (Time clause is modified) [I remembered I could hear the sound of the flute (i.e. truly appreciate a flute sound) only after I met Dide] (W-RA16B2A-0406-669)

Sadece and yalnızca occur as part of the phraseology "sadece/yalnızca .....değil (aynı zamanda optional) .... de/da," which corresponds to the English paired conjunction "not only .... but also ....". When the paired conjunction modifies two finite verbs, the phraseology is formulated as "sadece ...verb +mAklA kalmaylp or kalma- (finite) (ayn zamanda) .... de / da + verb (finite)." 
(11) Denizli, "futbolumuzu sadece taraftarlarımız değil, rakipler de beğenecek" dedi. [Denizli said "not only our supporters but also our opponents will like our football"] (W-MI31D1B-2339-3)

(12) Festival çerçevesinde katılanlar sadece güzel zaman geçirmekle kalmayıp Iveco araçlarını $\boldsymbol{d a}$ yakından inceleme firsatı buluyorlar. [In the festival visitors not only have a good time but also find the opportunity for a close look at the vehicles of Iveco] (W-MF25D1-2788-2)

(13) Şimdi yalnızca bizim mahalledekiler için değil, başka semtlerden gelen insanlar için $\boldsymbol{d e}$ dikiş dikiyor annem. [Now my mother makes clothes for not only those in our neighbourhood but also those from other districts] (W-MA16B2A-1950-1)

"Degil" in this collostructure is the negative copula in Turkish and ranks first in both sadece's and yalnızca's lists of collocates retrieved with a $-2+2$ span. "Değil" is a grammatical category, so sadece's and yalnizca's co-occurrence with it should rather be termed as colligation. That is, these exclusive adverbials often colligate with the negative copula "değil" as part of Turkish paired conjunction.

In the above examples (from 3 to 13), sadece and yalnizca are perfectly interchangeable. Derived from the Turkish adjectives sade (pure) and yalnız (alone/lonely) through the addition of adverb forming suffix $-\mathrm{cA}$, these exclusive adverbials have become frequently occurring functional words which "restrict the applicability of what is being said to the focus constituent of a sentence" (Göksel and Kerslake, 2005:212). Therefore, we do not focus on "sense" differences between these adverbs, but on their functions, which have seemed to be the same so far in the above examples.

\subsubsection{Sadece and Yalnızca as Postmodifers in Final Position}

Sadece and yalnizca are sometimes moved to the end of the phrase or clause that they modify. This syntactic change places them at sentence/utterance-final position, usually after the main verb. In such examples, sadece and yalnizca function as anaphoric modifiers of sentential constituents. If these adverbs do not modify the whole verb predicate before them in their sentence-final position, the phrase or clause modified by sadece and yalnizca occurs or ends at $-\mathrm{N} 2$ position. [i.e. XP (modifiee) + verb + nodes sadece/yalnızca (anaphoric modifier)]

(14) Geriye keyif verici bir istirap kaliyor sadece. [What we finally have is only a pleasant pain] (W-NA1B1A-1736-1) 
(15) Filistinliler şu anda Batı Seria, Gazze ve Doğu Kudus'ü istiyor sadece. (Multiple NPs + verb + sadece) (Now the Palestinians want only the West Bank, Gaza and East Jerusalem) (W-RE30D1B-2132-3)

(16) Ben, mutlu olduğumuz anları anımsıyorum yalnızca. [I remember only the moments when we were happy] (W-OA16B1A-0103-1)

In some examples sadece and yalnızca have summative or clarifying functions. The writer / speaker summarises the issue under discussion with a summative, clear and concise point. The overall meaning is " $\mathrm{X}$ is in fact nothing but ..." Because the focusers sadece and yalnizca occur after the focussed sentential element instead of being placed in their usual position -before what is to be focused, it seems that the user expresses the strikingly summative or clarifying point even before the exclusive adverbials which are meant to focus on them as pre-modifiers. It is a marked usage. With the exclusive adverbials placed at final position, the summative or striking point made by the user for the topic under discussion is expressed as soon as possible and sadece or yalnizca behave like a pragmatic full stop intended to imply that whatever has just been expressed is what can ultimately be said about the topic. Consider the following examples from the corpus:

(17) Harfin ve sözcüğün bu bağlamdaki kullanımı, bilişsel bir işlev üstlenmez. Sözcüğü ya da cümleyi görür ve duyarız sadece. [The use of a letter or a word in this context cannot have a cognitive function. What we only (simply) do is (nothing but) to see or hear the word or the sentence] (WQE39C2A-1430-1)

(18) Yani frenemy kavramı eski bir şarabın yeni şișelerdeki servisi sadece. [That is, the concept of frenemy is only (nothing but, simply) the service of old wine in new bottles] (W-WI22F1D-4713-1)

(19) Sanat yaşamın çocuğudur. Yaşamdan doğar. Bu nedenle biçimsel bir oyun olamaz resim yapmak. Yaşam hep önündedir sanatın. Aslolan yaşamdır. Yaşam daha trajik, komik, çirkin, güzel, umarsı, umutludur sanattan. Sanat yaşamın izdüșümü olmaya, yaşama yanıt veren yașamınkine denk bir dizge olușturmayı çabalar sadece. [Art is the child of life. It arises from life. For this reason drawing pictures cannot be a formal game. Life is always ahead of art. What really matters is life. Life is more tragic, funnier, uglier, more beautiful, more hopeless and more hopeful than art. (The simple and conclusive fact about art is that $\Rightarrow$ ) Art only (simply) struggles to be a projection of life, to create a system equivalent to that of life which reacts to life] (W-PG24D1B-2301-1)

(20) Daha fazla mal, daha fazla mülk, daha fazla para edinebilmek için hayatımızı yasayamadan harcıyoruz. Oysa insan hiçbir şeye gerçek anlamda sahip olamıyor. Ölene kadar kiralıyoruz yalnızca. Ve adımız 
anılsın diye mal mülk bırakıyoruz geriye. [In order to possess more goods, more property, more money, we waste our lives without living actually. However, people cannot possess anything in a real sense. We are only (simply, do nothing but) tenants of our possessions until we die. And we leave the property away for our remembrance] (W-JI22C2A-0797-670)

These are just the observations that we had about the concordance lines in the corpus that end with sadece and yalnizca. That summative or clarifying function of these adverbials cannot be limited to its sentence/phrase-final position of course. They might as well connote such functional meanings whether they are sentence-initial, sentence-internal or sentence-final. I would suggest that the reason for delaying the use of sadece or yalnizca to the end of the sentence or phrase might be the user's intention to present the focussed summative/clarifying element first and then the modifier sadece or yalnizca. In other words, he/she might regard the use of sadece/yalnizca (only) before the focussed element as a blotch on the landscape. Thus he / she prioritises the presentation of the summative/clarifying point and relegates sadece/yalnizca to the end of the point made. In such a case, it is ironic that the pre-modifier focusers (sadece/yalnızca) themselves are seen as an obstacle to maximal focussing when they are used in their usual position - thus become postmodifiers. Let's take a closer look at example 18:

a) Yani frenemy kavramı eski bir şarabın yeni şișelerdeki servisi sadece. (final position) focused element (summative point) + focuser

b) Yani frenemy kavramı sadece eski bir șarabın yeni șișelerdeki servisi. (as a premodifier) focuser + focused element (summative point)

This sentence comes after a long discussion of the meaning of "frenemy" (a blend formed by clipping parts of "friend" and "enemy" and combining the remnants into "frenemy" - an enemy that pretends to be friend). In the sample concordance line 18, thanks to the contribution of discourse particle yani (=that is), which also has a clarifying or summative function, the sentence would have a summative value without sadece of course. But what if the sentence were expressed without yani (= that is)? Then the sentence would only retain its summative value on condition that we keep sadece in the sentence whether it be before or after the focussed element.

In both $\mathrm{a}$ and $\mathrm{b}$ above, the propositional content is the same. But in utterance a, the focused element is more focussed because its lexical load is reduced with the deletion and movement of a word (only). In utterance b, we express the same propositional content but we must first read or hear sadece before we see or hear the focussed element which expresses the speaker / writer's summative point. Then for the reader or hearer of that 
sentence/utterance, sadece's usual syntactic location poses a one-word-length obstacle to readily reading or hearing the focused element expressing a summative point.

To sum up, sadece and yalnizca at sentence/utterance-final position in such examples as 17-20 pragmatically function as a "lock"; they have the meaning "nothing but or simply." They signal that the best summative / clarifying point has been said about the issue under discussion or analysis. There is no further thing that the writer / speaker could say in a better way and the summative point is readily expressed with the exclusive adverbials sent to the end of the utterance. Sadece and yalnızca stand at the end like a pragmatic full stop.

\subsubsection{Could Sadece / Yalnuzca Be Placed at Final Position for Concerns of Disambiguation?}

In some cases the location of the exclusive adverbial at final position has a disambiguating power. In Turkish the head of phrases is the last word in the phrase. Therefore, sadece and yalnizca at the end occur next to the head, thus preventing the possibility of them ambiguously modifying other constituents in the phrase separately. That is, there can be pragmatic motivations behind the speaker/writer's movement of sadece/yalnizca to the end of a phrase or clause. Thus any structural ambiguity is prevented. Consider the following examples:

(21) Meriç, Tuna’ya sahip olmak istedi yalnızca. [Meriç only wanted to possess Tuna $=>$ What Meriç only wanted was to possess Tuna] (WJA16B4A-0146-181)

(22) Perdelerini kapatmakla yetindiler sadece. [They just confined themselves to drawing their curtains] (W-VA14B1A-1606-1126)

(23) Maske bir yanda eğlencenin bir parçası sadece. [The mask is only a part of the entertainment] (W-TE36E1B-3295-1667)

In 21, yalnizca (only) might be placed before Tuna'ya, which would mean the same as when it is placed at the end of the verb phrase. However, such a placement could cause a structural ambiguity with yalnızca modifying only Tuna'ya. Two possible meanings when yalnızca is put before Tuna'ya can be explained as below:

Meriç, yalnızca Tuna'ya sahip olmak istedi. (structurally ambiguous)

a) Meriç, [yalnızca Tuna'ya] sahip olmak istedi. (only + noun phrase with dative case marker) [i.e. Meriç wanted to possess [only Tuna]]

b) Meriç, [yalnızca Tuna’ya sahip olmak istedi]. (only + verb phrase) [i.e. What Meriç only wanted was to possess Tuna] 
The placement of yalnizca in concordance line 22 above might then be motivated by the user's intention to disambiguate the utterance/ sentence, cancelling the meaning in a) above.

In concordance line 22 above, moving and fronting sadece (only) to the beginning of the verb phrase can again cause a structural ambiguity. Look at the ambiguous form of the sentence and two possible meanings which might arise depending on stress in speech and contextual environment in writing:

Sadece perdelerini kapatmakla yetindiler. (structurally ambiguous)

a) [Sadece perdelerini] kapatmakla yetindiler. (only + noun phrase with possessive marker and accusative case) [i.e. They drew [only the curtains], not any other thing].

b) [Sadece perdelerini kapatmakla yetindiler]. [i.e.They simply/just drew the curtains, but did no other thing]

Then with sadece (only) at final position in concordance line 22, the speaker/writer might aim to disambiguate the utterance/ sentence so that it won't mean like a) above. Likewise, in 23 above, placement of sadece before the word eğlencenin might cause sadece to modify this word alone instead of the whole noun phrase eğlencenin bir parçast. All in all, the hypothesis that the movement of sadecelyalnizca (only) to the end of a noun phrase or verb phrase is motivated by concerns of ambiguity might not be proven with a few examples; however, the final positioning of these exclusive adverbials has a secondary benefit of disambiguation in some cases.

\subsection{Lexical Profile of Yalnız}

\subsubsection{Semantic Analysis and Its Phraseology}

Because yalnız is polysemous and has distinct pragmatic features, we deem it right to analyse its concordance lines separately to show its idiosyncratic lexical profile as compared to sadece and yalnızca above. Yalnız occurs 14607 times in the written section of the corpus TNC v3.0. When used as an exclusive adverbial, yalnız corresponds to the English word only just like sadece and yalnızca. Naturally, it shares their semantic and syntactic properties in that when it means only, it modifies various phrases or speech parts in the same way as them. In the following concordance lines, yalnız is intersubstitutable with sadece and yalnizca.

(24) Sonra dost düşman bütün insanlar birden sustu. Yalnız analar ağladı. $(y a l n ı z+\mathrm{NP})$ [Then all the people, whether friends or enemies, suddenly went silent. Only mothers cried] (W-MA16B1A-0163-1) 
(25) ...Yani yalnız niceliksel değil, niteliksel temsil istenmektedir. (yalnız + adjective) [That is, not only quantitative, but also qualitative representation is required] (W-MD02A3A-3320-1)

(26) ...her spermde yalnız bir S geni bulunur. (yalnız + quantifier) [...only one $\mathrm{S}$ gene is found in each sperm] (W-MB04A3A-1020-2)

(27) Böylece albüm insanın yalnız kulağına değil, yüreğine de sesleniyor. (not only ...but also ... function) [Thus the album appeals to not only your ears but also your heart] (W-TE36E1B-3295-1029)

In these lines yalnuz is an exclusive adverbial which means only like sadece and yalnızca. However, in most lines we see yalnız as an adjective in the sense of alone/lonely. When yalnız means alone or lonely, it often collocates with certain verbs (kal-, ol- and birak-). In such cases, yalnız is sometimes used attributively like lonely as part of a noun phrase (lonely+noun), while in others it is used predicatively. As an adjective yalnuz means alone or lonely, which is a more emotive concept compared to alone. As an early hypothesis, we would say that yalnız is synonymous with sadece and yalnızca in one of its senses (i.e. adverbial function); hence the synonymy relation is partial. Below are examples for yalnuz's use as an adjective meaning alone/lonely.

(28) Kalabalık bu kadar gürültülü olmasaydı, ben bu kadar yalnız ve sessiz olmayacaktım. Yalandı oysa... (yalnız means lonely, not only) [If the crowd hadn't been so noisy, I wouldn't have been so lonely and quiet. Nevertheless, it was unreal...] (W-MI41C3A-0876-1)

(29) İşte o zaman yalnız çocuk bir şeyi daha anlar. (the lonely child, attributive use) [Just then the lonely child understands one more thing] (WMA16B4A-0126-5)

(30) ...bir yaşa kadar evde yalnız bırakılmaları sakıncalı olabiliyor. (yalnız means alone; on their own) [It can be objectionable until a certain age that they (children) are left alone at home] (W-MD36E1B-2855-1)

\subsubsection{Pragmatic Features of Yalnız}

Yalnız sometimes means neither only nor alone/lonely. It is roughly equivalent to the Turkish discourse connector ancak (but, however). Nevertheless, the way it is used in the concerned lines does not seem to correspond to ancak (but) at all times. In some cases, yalnız functions as a pragmatic device or discourse particle that signals certain messages that will follow. Consider the following lines and the subsequent discussion:

(31) Pratik olarak ölülerden organ alınması söz konusu yalnız (ancak) burada ölümün özel bir tanımlamasını yapmamız gerekiyor. [Organs can be 
harvested from the dead in practice, but we have to make a specific definition of death first] (W-LD43A3A-1798-438).

(32) 2sene öncesine kadar da aynı sütü kullanıyordum yalnız (ancak) maya olarak aldığım yoğurt farklıydı. [Until two years ago I used the same milk, but the youghurt I bought as yeast was different] (W-UI44F1D-51182448)

(33) Meyveli yiyecekler yiyebilir, komposto, reçel yapabilirsiniz. Sportif faaliyetler için uygun, yalnız yüzünüzü koruyun. [You can consume foods containing fruit, make compote or jams. That is advisable for sports activities, but (it is a word of caution that) protect your face] (WTE36E1B-3353-1)

(34) Şimdi de kendini o filmlerden birinin aktörü yerine koy. Yalnız bizim evde kabadayılık sökmez haberin olsun! ... (And now imagine that you are an actor in one of those movies. But (I warn you that) our home is not a right place for bravado, is that clear?!..) (W-NA16B4A-0431-152)

(35) "Abidin buraya gelsen birkaç günlügüne, gelebilir misin? Onunla konuşsan..." "Gelirim Türkan Abla. Yalnız Nergis İstanbul'da, haftaya gelecek. Can benimle birlikte. Nergis gelince..." (Abidin, I wish you would come here for a few days, wouldn't you? If only you would talk with her..." "I will, Türkan Abla (Sister Türkan, a way of addressing). But (I hereby inform / remind you that) Nergis is in İstanbul. I'm staying with Can. When Nergis returns..." (W-UA16B2A-1041-1)

(36) Ailenizdeki insanların sağlığıyla uğraşmak zorunda kalabilirsiniz. Kariyerinizle ilgili kafanız süratli çalışacak, yalnız parasal alanda zorlanmalarınız olabilir. [You may have to deal with a family member's health. You will keep being smart in your career, but (be warned, prepared that) you may experience monetary problems] (W-TE36E1B3355-1)

(37) Serra Tokar da beyaz dekolte elbisesiyle göz kamaştırıyordu. Yalnız ben Serra'ya hâlâ kırgınım! Ayol neden olacak, hiç hoşlanmam öyle sudan sebeplerle boşanmalardan. [Our eyes were dazzled by Selda Toker in her white décolleté dress. But (by the way) I'm still disappointed with Serra. Ayol (a way of a woman's addressing another woman) Don't ask me why, because I don't like people divorcing for trivial reasons at all (WUE36E1B-3357-8)

(38) R : Yemin ediyorum var ya yok canlı izledim ben onu biliyon mu sen.

$\mathrm{S}$ : Ben sonradan dinledim ya.

$\mathrm{R}$ : Kardeeş. Bu lafın bak bu ıslığın üstüne başka bişey demiyorum ben. Yani tek geçer bomba birader.

S : Yalnız adam yaşlanmış biraz. Saçlar beyazlamış sadece biraz.

[R : I swear I watched it/him live, do you know that?

$\mathrm{S}:$ I listened to it/him afterwards. 
$\mathrm{R}$ : Brother. I won't make any further evaluative remarks after your words and this whistle yours (whistle should be indicator of one's amazement). That is, no more words are needed to express my amazement.

$\mathrm{S}:$ But (by the way) the man seems to have grown a bit older. His hair has gone grey just slightly] (Spoken part of the corpus. S-BEABXO-008630)

In concordance lines 31 and 32, yalnız is a discourse connector which simply means ancak (but). On the other hand, in the above 8 concordance lines it is clear that one cannot run away with the idea that yalnız means ancak in Turkish and that is all, as it is presented by TDK online dictionary. If it were the case, we would not have added the bracketed descriptions next to but in their translation equivalents. One could also say that if ancak replaced yalnız in those lines, ancak would also signal those same pragmatic meanings. However, yalnız does not simply sound like ancak in the last two examples because it is neither an adversative connective nor introduces an unexpected result or an implied condition. This is the semantic schema in 37: the speaker is talking about people's clothes and actions at a party. First what Serra was wearing is expressed, and then with yalnız the topic of conversation is shifted to Serra's private life (she has gotten divorced). Yalnız has the discourse function of signalling a topic shift, functioning like the English lexical unit by the way.

To summarise the functional meanings of yalniz in the above lines, it could be said that in example 33, yalnız marks a warning, requirement or exception to be added; in 34 after yalnız the addressee is warned of a fact about our home, a requirement that the addressee should not do bravado at that home; in $36 \mathrm{yalnuz}$ signals that the speaker will add a reminder of an important piece of information that should be taken into consideration about the issue discussed. It adds the implied condition that if Nergis were not in Istanbul now, Abidin would go and visit Türkan Abla at once. In 36 yalnız occurs in a text describing one's horoscope. After yalnız we see a warning. As we said in the previous paragraph, yalnız in sample lines 37 and 38 functions as a topic shifter, probably like by the way in English. Then if yalnuz does not mean only like sadece and yalnizca or alonellonely, it can be concluded that in the Turkish speech community the human mind expects a warning, reminder, a requirement, an implied condition or a topic shift as soon as one hears the word yalnız. That is exactly what a pragmatic function means for an item.

\subsubsection{Yalnı As Used in Utterance / Sentence Final Position}

We have already determined and discussed what meanings or pragmatic functions that the other exclusive adverbials in our synonym set (sadece and yalnızca) have when used as a final word in a sentence or utterance. In order to 
test whether yalnız has a similar function in utterance-final position, we looked at 39 lines ending with yalnız. In 21 lines it means alone or lonely; in 8 lines it anaphorically modifies an NP or another phrase at L2 or ending at L2 position of the node; in 8 lines it has a sentential scope. Unless the utterance consists of only two words, yalnız at final position never modifies the preceding word at L1 which is almost always the main verb of the sentence. Sample lines:

(39) Perde ardına kadar açık. Anlaşılan o da yanındakilerden yalnız. [The curtains are fully drawn open. Apparently she is lonelier than those with her] (W-JA16B4A-1093-1)

(40) ...Tanrıça içeride yalnız. [The Goddess is alone inside] (W-CI22C3A1079-1)

(41) Savruluştan kasıt mesafeler değil yalnız. [What is meant by hurling is not only distances) (NP "mesafeler" at L2 is modified] (W-OI22C1A-083334)

(42) Nadya, suskunca izliyor yalnız. [Nadya is just watching quietly-sentential scope, the whole verb predicate is modified] (W-DA16B4A-0384-1)

In two lines, we identified yalnız as a discourse marker with the function of signalling a reminder or a warning.

(43) Bernard Shaw bir derin kuyuya benzer yalnız. Taş atmak kolaydır içine; ama bu taş dibe inecek olursa... (reminder or warning about an important point) [(I hereby remind or warn you that) Bernard Shaw resembles a deep well. It is easy to throw a stone into it; but if that stone happens to reach the bottom...] (W-UA16B4A-0695-2)

(44) ...Allah'ın belası bir herife çattık yalnız. Uzman mühendismiş! Resmen dolandiric1. (reminder of a situation) [(I must remind / inform you that) we have struck a Goddamn man. He is purportedly an expert engineer! He is a real con-artist] (W-VA16B2A-0561-1)

It can be concluded from these lines that yalnız in final position retains its usual senses and functions observed at its sentence-internal or -initial position. The meanings and functions of yalnız can be summarised as below: 
Table 1. The summary of semantic and pragmatic features of yalniz.

Meanings and Functions of Yalnız in Turkish

1 The sense only + phrases (premodifying exclusive adverbial)

2 Phrases + the sense only (at sentence/utterance final position)

3 Forming a paired conjunction (not only ...but also function)

4 Summative / clarifying function at final position (marginal)

5 Imposing a requirement or condition (implied condition marker)

6 Informing / Reminding

7 Warning / word of caution

8 "By the way" meaning (Topic shifter function)

9 The senses alone/lonely (Adjective function)

The following table (Table 2) shows how intersubstitutable sadece, yalnizca and yalniz on the basis of their distinct senses or functions:

Table 2. The semantic and pragmatic landscape of yalnız, sadece and yalnizca.

\begin{tabular}{llccc}
\hline & Meanings and functions & Yalniz & Sadece & Yalnizca \\
\hline 1 & The sense only + phrases (premodifier) & + & + & + \\
2 & $\begin{array}{l}\text { Anaphoric only (at sentence-final } \\
\text { position) }\end{array}$ & + & + & + \\
3 & Forming a paired conjunction & + & + & + \\
4 & Summative / clarifying function at final & $+?$ & + & + \\
& position & + & None & None \\
5 & Imposing a requirement or condition & + & None & None \\
6 & Informing / Reminding & + & None & None \\
7 & Warning / word of caution & + & None & None \\
8 & By the way / topic shifter function & + & None & None \\
9 & Adjective use (the senses alone / lonely) & & & \\
\hline
\end{tabular}

From Table 2 it seems clear that sadece and yalnizca are completely intersubstitutable in terms of their meanings and functions, while yalniz is partially synonymous with the other exclusive adverbs; that is, when the meaning is only; when they are part of the phraseology "sadece/yalnizca/yalnız ......değil (aynı zamanda) ...de/da" or perhaps when they have the summative/clarifying function. The area of intersubstitutability is marked grey in Table 2 above. The last 5 rows demonstrate for which senses and pragmatic functions neither sadece nor yalnizca can be substituted for yalniz. We think that a more illustrative and conclusive discussion of their intersubstitutability and synonymy should be made after their collocational and colligational patterns have also been analysed - to exactly "decide in what circumstances substitution of one item for another is possible in a text" (Partington 1998:29). 


\subsection{Collocation and Colligation Analysis}

Except for yalniz, the other two words in our potential synonym set - sadece and yalnızca- have only one meaning of "only" and some pragmatic function at final position and they are mostly used as exclusive adverbials which may modify various speech parts, phrases or clauses. Therefore, these words, including yalnız, when it is used as a focus adverbial, can co-occur with any words or phrases, which means a list of typical collocates should be out of the question for them. However, we got 'collocation' lists of sadece and yalnizca from the TNC v3.0 and noticed that the words in the list display grammatical categories, which means they should be regarded as colligates rather than collocates. Strangely enough, our findings demonstrate that the top 15 'collocates' for sadece and yalnizca are almost overlapping. We see 12 common words in their top 15 collocates (değil, bir, bu, ve, için, ise, ben, o, birkaç, ama, kendi, iki. See Appendix 1 and 2). This is another proof of their high intersubstitutability (Divjak, 2010:122).

The negative copula degil (not) ranks the first in the collocates list. Sadece, yalnızca and yalnız often colligate with this word because it is part of the paired conjunction "sadecelyalnızca ....."değil" (aynı zamanda optional) ... de/da," which corresponds to the English paired conjunction "not" only .... but also ...." The words ve (and) and sadece itself are part of the phraseology sadece ve sadece (Lit. only and only) and the collocational pattern provides a more emphatic way to focus on an exception, restriction or a quantity, precisely excluding all other possibilities. The pragmatic motivation behind the Turkish speaker's choice of the reduplicated forms of the exclusive adverbials - sadece ve sadece, yalnizca ve yalnızca and yalnız ve yalnız - is to enable the exclusive and restrictive power of "sadecelyalnizca/yalniz (only)" to reach its zenith. The further emphasis produced by reduplication adds the sense "certainly and indisputably only x."

(45) Egemenlik ve söz hakkı sadece ve sadece İngiltere'ye aitti. [Sovereignty and the right to speak belonged solely to England] (..indisputably only, solely England, to the exclusion of any other country). (W-ME39C3A0581-74)

(46) Ferhat, Padişah'a, altın istemediğini, yalnızca ve yalnızca Şirin'i istediğini söyledi. [Ferhat told the Sultan that he did not want gold, but wanted only/solely Şirin] (...certainly no other thing or person than Şirin) (WEA16B1A-0096-6)

(47) Dedelerimin yalnız ve yalnız tarlada pamuk toplamaya hakları vardı. [My grandfathers had only the single right to pick cotton in fields] (WGG37C3A-0399-30) 
Divjak (2010:123) states that "combinatorial patterns are prevalent in corpus linguistics and are typically interpreted as reflecting semantic and/or pragmatic characteristics." This is also the case for the collocational/colligational patterns that we see in sadece and yalnizca's lists of top collocates such as ama sadece/yalnizca (but only), artık sadecelyalnizca (now only), X yok sadecelyalnizca $Y$ var ( $X$ is non-existent or irrelevant, there is only $Y$ ), ben sadece/yalnizca (I only/just) and ise sadece/yalnızca (as for / whereas + only). These co-occurrence patterns reflect linguistic schemas motivated by underlying pragmatic concerns. In the collocational patterns that will be analysed and exemplified below sadece and yalnizca are completely intersubstitutable, so both are particularly used in the titles. On the other hand, yalnız, which is a cognitive synonym of them only in the sense of "only," has other meanings and will be included in discussions whenever it is relevant.

\subsection{1 “Ama” at-N1 position (i.e. Ama Sadece / Yalnızca)}

Ama sadece / yalnizca (but only) reflects a linguistic schema in which a general point, claim or quantity is expressed and after ama sadece / yalnizca the speaker / writer expresses a restriction or exception to the point made. They add a striking contradiction which they expect the addressee to focus on exclusively.

(48) Türkiye'de 10 yıl önce de kredi kartı vardı ama sadece üst gelir grupları tarafindan kullanılmaktaydı. [There were credit cards in Turkey 10 years ago too, but they were used only by upper income groups] (WMF1DE1B-2864-33)

(49) Çileklerse çilek çilek kokar ama yalnızca tazeyken. [And strawberries smell of strawberries but only when they are fresh] (W-GA1B2A-192494)

We wondered whether ama and yalnız form a lexical partnership (ama yalnız) to reflect the linguistic schema above. We obtained 92 lines in which yalnız colligates with ama (but) at $-\mathrm{N} 1$ position. However, we saw that yalnız means alone or only in most cases and ambiguous in some. Rare examples with yalnız demonstrate that the collocation strength between ama and sadece / yalnizca is much stronger than that between ama and yalniz for the same function. The following example can be cited as similar to the function of ama sadece / yalnızca exemplified above.

(50) Kendimi edebiyatçı sayıyordum, ama yalnız edebiyat tarihçisi ve belki de eleştirmen olarak. [I regarded myself as a man of literature, but only as a historian of literature and perhaps as a critic] (W-TI09C3A-1229-91) 
Table 3. The co-occurrence frequency of "ama" at-N1 with sadece, yalnizca and yalniz on the basis of data from TNC v3.

\begin{tabular}{|c|c|c|}
\hline Lexical Bundle & Number of Occurrence & Frequency in One Million \\
\hline ama sadece & 322 & 6,48 \\
\hline ama yalnızca & 116 & 2,34 \\
\hline ama yalnız ${ }^{l}$ & 92 & 1,85 \\
\hline
\end{tabular}

From Table 3 it is clear that the biggest collocation strength is between ama and sadece, with yalnizca ranking the second and yalnız proving to be too marginal.

\subsection{2 “Artık” at-N1 position (i.e Artık Sadece / Yalnızca)}

The collocational pattern artık sadece / yalnızca (now only) gives the idea that a situation has changed, which can be readily understood from artık (Turkish word for now, any longer, no longer). However, with the addition of the adverbials sadece / yalnizca, the whole pattern is chosen when a big change has happened in a situation and after sadece / yalnizca, we see what now remains compared to the past and it is quite limited in scope, content or quantity. Thus the lexical partnership artık sadece / yalnızca reflects a big gap between the past situation and the present one.

(51) Mesela Osmanlı çileğini artık sadece kendi tüketimleri için üretildiği köylerde görebilirsiniz. [For example you can now see Ottoman strawberries in villages where they are grown only for their own consumption] (a big change about strawberries - from much more common in the past to much less common in limited places) (WTE36E1B-3295-164)

(52) Tanımadığımız insanlarla aramızdaki ilişki artık yalnızca çatışma ve kavga ilişkisine dönüşüyor. [Our interactions with strangers are now becoming only one of conflict and fight] (a big change from our earlier more and better interactions to a limited and worse kind of interaction) (W-JA16B2A-0873-90)

Artık (now, any longer, no longer) ranks 32th in yalnız's top collocates list. The phraseology "artık yalnız" appears 74 times in the corpus and quite naturally in

1 The lexical bundle ama + sadece, yalnizca" corresponds to "but only" in English, while ama + yalniz rarely do so because yalnız is often used in the sense of alonellonely. Therefore, you should consider the figures in Table 3 for "ama yalniz" accordingly. That is, it is much more infrequent than it seems in Table 3. 
more than half of the lines yalniz means alonellonely or is part of a paired conjunction. There are a few examples in which artık yalnız functions like artık sadece / yalnizca to express a big change between the past and the present situation of something.

(53) Belki bu "ayıp" yüzünden eski Yunanlıları, büyük filozofları, destan şairlerini, Heraclit'i, Anaximander'i, Thales'i yetiştiren topraklarımızda, bugün artık yalnız işadamı ekip işadamı biçiyoruz. [Perhaps because of this "shame," we now only raise businessmen in our territories which used to raise ancient Greeks, great philosophers, epic poets, Heraclit, Anaximander and Thales] (W-II22C3A-0566-69)

While artık sadece and artık yalnızca tend to manifest big changes between the past and the present, artık yalnız does so in some selected examples, which is strictly context dependent.

Table 4. The co-occurrence frequency of "artı" at-N1 with sadece, yalnızca and yalniz on the basis of data from TNC $v 3$.

\begin{tabular}{lll}
\hline Lexical Bundle & Number of Occurrence & Frequency in One Million \\
\hline artık sadece & 245 & 4,93 \\
artı yalnızca $^{2}$ & 94 & 1,89 \\
artıkyalnız $^{2}$ & 74 & 1,49 \\
\hline
\end{tabular}

Table 4 clearly demonstrates that the collocation strength is at its peak between artık and sadece, with the other adverbials seeming unwilling to form a lexical partnership with artık.

\subsection{3 ...X...Yok Sadece / Yalnızca...Y...Var ( $X$ is non-existent (but) only $Y$ is existent) ("yok" at-N1 position, "var" at sentence/utterance position)}

Another top collocate at -N1 position is yok (Lit. non-existent), thus we get the collocational pattern yok sadece / yalnızca. The pattern usually co-occurs with the existential particle var. One's initial impression of this collostructure is that the speaker / writer simply says what there is not in a place but only what there is. In other words, it should mean "there isn't $\mathrm{X}$ but there is only $\mathrm{Y}$."

\footnotetext{
2 In more than half of the 72 cases, yalnız means alonellonely. Only in a few cases "artık yalnız" behaves like "artık sadece / yalnızca." Therefore, the figures for yalnız in the table should again be considered accordingly.
} 
(54) 100 yıl önceki Toroslar'da çekilen fotoğraflarda keçi yok, sadece koyun var. [In the photos taken in the Toroslar mountains 100 years ago there aren't goats, (but) there are only sheep] (W-UE36E1B-3358-179)

However, the concordance lines reveal that the word yok (lit. non-existent) in this pattern sometimes connotes denial of, objection to or inapplicability of the XP before yok. After sadece / yalnizca in the pattern we see the only thing that is relevant, marked with var (Lit. existent). The pragmatic motivation behind this collocational pattern sometimes is that the conceptual content of a concept or its definition is objected to, reduced or redefined. The true meaning of a concept or phenomenon becomes open to dispute. In such concordance lines, the semantic schema is that something is incorrectly defined, categorised or included in a category and the speaker / writer objects to or falsifies this with yok and after sadece / yalnizca he/she expresses what he/she believes to be the sole truth with respect to the wrongly understood entity mentioned before $y \boldsymbol{o k}$.

(55) “Çağımızda aşk, maşk yok, sadece maddi çıkar var, etsel alışveriş ve seks var..." [In our age there isn't anything like love, (but) there is only mutual material interest, flesh exchange and sex...] (W-IA16B2A-0771181)

In this concordance line, the writer/speaker redefines today's so called love in a different way, including new entities while reducing other entities in the conceptual content of "true love"

(56) "Babalık diye bir müessese yok, sadece spermlerini satmak diye ticari bir olay var." [Lit. There is no institution like paternity, (but) there is only a commercial concern to sell sperms] (W-DA16B2A0032-165).

In this line the Turkish user evaluates or defines a specific situation not as a true fatherhood but as a commercial event of selling sperms to potential mothers.

(57) İyi ve kötü yok, yalnızca güç var ve bir de bunu göremeyecek kadar zayıf insanlar... [There isn't anything like good or bad, (but) there is only power and those who are too weak to see that...] (W-OD02A1A-0849-43)

(58) Burada dostluk ve arkadaşlık kavramı yok, yalnızca bir tanışıklık var, zorunlu yaşama var. [In this situation there isn't anything like friendship or companionship (but) there is only acquaintanceship, or obligatory cohabitation] (W-CE09C3A-0382-36) 
In 58 the writer tells about a group of people living in the same place as a group. He makes comments on the relationship between the members of the group. He/she does not regard their relationship as true friendship but defines it only as acquaintanceship, or obligatory cohabitation. To sum up, in the above four lines the writer/speaker expresses what is irrelevant and what is relevant in a situation. He/she points out how something can be defined or categorised more correctly. In other words, he/she brings into question how something can in fact be defined or expressed more accurately. With the adverbs sadece or yalnizca, meaning only, he/she expresses the only redefinition or reconceptualization, which excludes other possibilities.

When the same pattern is examined with yalniz substituted for sadece or yalnızca, we have the pattern "yok yalnız." Yok ranks $100^{\text {th }}$ in yalnız's collocates list. Our special inquiry of the TNCv3.0 shows that yok and yalnız occur adjacently 53 times in the corpus and only in 11 lines do we see the simple pattern " $\mathrm{x}$ yok yalnız $\mathrm{y}$ var" (there isn't $\mathrm{x}$ (but) there is only $\mathrm{y}$ ). These lines lack the pragmatic motivation underlying yok sadece and yok yalnızca which was discussed above. The sentences express only what there isn't and what there is.

(59) Üflemeliler yok. Vurmalılar da yok. Yalnız piyano benzeri bir eski aygit var. [There aren't wind instruments. There aren't percussion instruments, either. There is only an instrument like the piano.]

Table 5. The co-occurrence frequency of "yok" at-N1 with sadece, yalnizca and yalnuz on the basis of data from TNCv3.0

\begin{tabular}{lll}
\hline Lexical Bundle & Number of Occurrence & Frequency in One Million \\
\hline yok sadece & 220 & 4,43 \\
yok yalnizca & 49 & 0,99 \\
yok yalniz & 53 & 1,07 \\
\hline
\end{tabular}

Table 5 shows that there is a much stronger collocation strength between yok and sadece with the one between yok and yalnızcalyalnız proving to be weak.

\subsection{4 “Ben” at-N1 position (i.e. Ben Sadece / Yalnızca)}

Sadece and yalnizca often collocate with ben (I) at L1 position. Our analysis of the relevant concordance reveals that the lexical partnership ben sadece / yalnizca (I just) has the pragmatic function of conveying self-justification for one's acts or thoughts. Ben sadece / yalnizca marks an attempt to clarify one's stance, to correct a misunderstanding about oneself, to imply an apology or to emphasize the sole purpose or cause of one's (usually earlier) deeds. Utterances including this pattern reflect the user's intention to get out of a difficult or 
awkward situation or a negative atmosphere that he/she causes or that is associated with him/her. The speaker/writer provides explanations for selfjustification in a display of modesty, sometimes to the degree of selfhumiliation like depreciatory meaning of just (Lee, 1987). The explanations after ben sadece / yalnızca sometimes sound philosophical. Sample lines:

(60) Hayır, ben tiyatroda hiç oynamadım kızım. Hem de hiç oynamadım. Ben sadece gerçeği, yaşamı oynadım ve oynuyorum da. (self-justification through philosophizing) (No, I have never acted in a theatrical play, daughter. Never ever. I have just played reality, life itself and still do so) (W-SA14B1A-4732-278)

(61) ...ittiğin doğru mu? Sanık, sakin bir ifadeyle yanıt verdi: -Ben yalnızca bir basamak ittim, ötekilerden kendisi düştü. (self-justification) (...is it right that you pushed him down the stairs? The defendant replied calmly: -I only/just pushed him one step down, he himself fell down the others) (WSI22C2A-0449-54)

(62) Muzır Ruşen" hariç, gerisi hep yaşamış, tarihe mal olmuş kişilerdir. Ben sadece onları unutulmaya terk edilmiş, tarihin tozlu sayfalarından bulup çıkardım. (Except for Muzır Ruşen, all are people who lived before and made history. I only/just dug them out of the dusty pages of history waiting to be forgotten) (display of modesty) ( (W-PI22E1B-2909-159)

(63) .... Nükleer Araştırma, kimisi ARGE, TÜBİTAK kuruluşlarında. Bu terimler anadilimizden doğmuştur. Ben yalnızca aracı oldum. Onun için bu terimler hepimizindir. [(some of these terms are used) ...in associations of Nuclear Research, R\&D and TÜBİTAK. These terms are products of our native language. $I$ was only/just a mediator. Hence these terms belong to all of us] (display of modesty) (W-OH36C4A-0237-10)

(64) Ben seni yenmek istemiyorum ki. Bunu hiçbir zaman istemedim. Ben sadece senin hayatında olmak istedim. (correct a misunderstanding about one's purpose) (I do not want to defeat you. I have never wanted that. $I$ only/just wanted to be in your life) (W-NA16B1A-0322-48)

(65) “...çay içmeyi istemiyorum," yanıtını verdim. Adam biraz gücenmiş bir tonda, "Ben sadece içeriden manzarayı görebilesin diye seni davet ettim. ..." (“...I don't feel like drinking tea" said I. The man said sounding a bit offended "I only/just invited you in for you to see the scene from inside." (correct a misunderstanding about one's purpose) (W-TE36E1B-3353-35)

(66) KADIN: Siz de alınganlık yapmak için firsat kolluyorsunuz! Ben yalnızca, olabilecek bir şeyden söz ediyordum. ADAM: Başka neler olabilir?(clarifying a misunderstanding, self-justification) (LADY: You seem to be so ready to be susceptible to anything I say! I was only/just talking about something that might happen. MAN: What else may happen?) (W-TA14B1A-1591-53) 
The sample concordance lines above reveal that ben yalnızca and ben sadece have the same pragmatic function. Then they are interchangeable lexical bundles in this respect too. That is, in these two-slot collocation patterns, the second collocate may be either sadece or yalnizca.

As for yalnız, "ben" ranks $8^{\text {th }}$ in its collocation list. However, at $-\mathrm{N} 1$ position, that is, the pattern we intend to see - "ben yalnız"- occurs 99 times in the corpus. However, this togetherness seems to result from coincidental cooccurrences rather than forming a lexical bundle to indicate a pragmatic purpose of marking self-justification or display of modesty. Only in 2 examples did we see a similar function. In other cases, "ben" meaning " $I$ " and "yalnız" meaning alone or lonely (+noun phrase) appear coincidentally together rather than form a lexical bundle to point to a discourse function. One of the two (rare) examples in which ben yalnız seems to function like ben sadece / yalnızca is below:

(67) Hitler'in yenilgisinden sonra, kapatıldığı hücrede, "Ben yalnız emirleri yerine getirdim... Gluecks emirleri Kalternbrunner'den aldı, ben de kurşuna dizme emrini aldım sonunda... [After Hitler's defeat, in the cell in which he was imprisoned, he said "I only/just fulfilled the orders ... Gluecks took orders from Kalternbrunner, and I was finally given the order to execute (them) by firing squad...] (W-MG37C3A-0006-94)

Table 6. The co-occurrence frequency of "ben" at-N1 with sadece, yalnizca and yalniz on the basis of data from TNC 13.0

\begin{tabular}{lll}
\hline Lexical Bundle & Number of Occurrence & Frequency in One Million \\
\hline ben sadece & 347 & 6,99 \\
ben yalnizca & 87 & 1,75 \\
ben yalniz & 99 & 1,99 \\
\hline
\end{tabular}

Table 6 demonstrates that the semantic priming between ben and sadece to serve the pragmatic functions described in detail above is extremely strong, while ben seems to be unwilling to co-occur with yalnızca and yalnız to express the same.

\subsection{5 "İse" at-N1 position (i.e. Ise Sadece / Yalnızca)}

This is another lexical bundle in which sadece and yalnizca are interchangeable. "ise" is a discourse connective with topic shifting or

3 In the majority of cases yalnı means alone/lonely. Only in two examples ben yalnız shares the pragmatic function of ben sadece/yalnizca. The number for ben yalniz in Table 6 is deceptive. 
contrasting function, which corresponds to as for or whereas in English. Ise often appears at $-\mathrm{N} 1$ position of our nodes sadece and yalnizca. This colligational pattern in a phraseology like " $X P+$ ise + sadece / yalnızca" is another recurring pattern as shown in top collocates lists in Appendix 1 for sadece and Appendix 2 for yalnizca. In the collocation frequency list, "ise" ranks seventh for sadece and ninth for yalnızca. The frequent lexical priming between ise and sadece / yalnizca led us to determine whether there is any pragmatic motivation. The constituents in the phraseology XP + ise + sadece / yalnızca are described as follows:

$\mathbf{X P}=>$ X phrase; mostly a nominal phrase which expresses a newly topicalized entity

Íse $\Rightarrow$ Discourse connective as topic shifter or contrastive connective corresponding to as for or whereas, respectively. "Ise" marks the XP to be focused among other entities already mentioned.

Sadece / Yalnizca => only, just. These exclusive adverbs are followed by a single feature of XP which distinguishes it from the previously mentioned entity / entities.

"Ise" is also the copular conditional marker in Turkish. However, in the pattern above, it is a topic shifter or contrastive connective which corresponds to the English expressions as for or whereas (Göksel and Kerslake 2005:448). In contexts in which ise means as for, it introduces a new entity to be topicalized after facts about other entities have been mentioned. When ise functions as whereas, we simply contrast the focused entity XP with another or others which precede XP in the co-text. Sample lines:

(68) Denizlispor, Fenerbahçe karşısına yedek ağırlıklı bir kadroyla çıkarken Sarı-Lacivertli takımda (XP) ise sadece kalede değişiklik yapılmıştı. (ise=whereas; contrast) $[$ Denizlispor played against Fenerbahçe with a team mostly consisting of substitutes, whereas in the team of the YellowDark Blue jerseys (XP) only the goalkeeper had been replaced] (WSI31D1B-2431-12)

(69) Yunan Meclisi'ndeki "Kıbrıs Dosyası" kayıtlarına göre darbe Yunanistan Cumhurbaşkanı Fedon Gizikis, Yunanistan Başbakanı Adamandios Andruçopulos, Cunta üyesi Dimitri İoannidi ve Silahlı Kuvvetler Başkanı Grigori Bonano tarafından düzenlenmişti. Samson (XP) ise sadece bir figürand1. (ise: as for; topicalisation) [According to the record of "Cyprus Folder" in the Greek Parliament, the military coup had been made by the Greek Premier Adamandios Andruçopulos, the Coup member Dimitri İoannidi and the Chief Commander of the Armed Forces Grigori Bonano. 
As for Samson (XP), he was only/just an extra. (W-ME39C3A-0581-448) (the depreciatory meaning of just (Lee 1987) is also clear in this instance)

(70) Suflör, gönüllü olsunlar olmasınlar insanlara kendi kafasındaki doğruyu empoze eder. Rehber (XP) ise yalnızca gönüllü olarak kendisine başvuranları seçeneklerle tanıştırır. (ise: whereas, contrast) [A prompter imposes his/her own truths on people whether they are willing or unwilling, whereas a guide only introduces options to those willingly consulting him/her] (W-SC03A2A-1306-39)

(71) Postadan kendisine kitap ve dergiler gelirdi. Gelen paras (XP) ise yalnızca yemeğini karşılardı. (ise: as for; topicalisation) [The postman used to bring him books and journals. As for money orders arriving (XP), it only covered his meal costs.] (W-PA14B4A-1627-58)

The pattern "XP ise sadece / yalnizca" functions as a double focuser with ise focusing XP (as opposed to other entities previously mentioned) and sadece / yalnızca focusing a feature of XP (which distinguishes it from the other entity or entities mentioned). In this lexical partnership ise sadece is like lens maximally adjusted to display a clearer picture of the focused entity. "Ise sadece / yalnizca" can at times reflect the focused disadvantage of the focused entity. In such cases XP is victimised; ise points to the victim and sadece / yalnizca delivers a blow to it.

(72) Yabancı sermaye yatırımlarının GSMH içindeki payı, Singapur'da yüzde 14.3, İngiltere'de yüzde 8 , Türkiye'de (XP) ise sadece binde 3. Araştırmada, Türkiye, "vergi cehennemine", vergilerini düzenli ödeyenler "tüyleri yolunmuş kazlara" benzetildi. (ise: whereas, contrast) [The share of foreign capital investments in GDP is $14.3 \%$ in Singapur, $8 \%$ in England, whereas in Turkey (XP) it is only 3 per thousand. In the research report, Turkey was compared to "tax hell" and the regular tax payers to ducks with feathers plucked) (W-OI27D1B-2815-362)

"Ise" ranks $365^{\text {th }}$ in the collocates list of yalniz! The collocational pattern "ise yalnız" with ise at $-\mathrm{N} 1$ position occurs 48 times in the TNC v3.0. In 13 of them yalniz does not mean only, but alone or lonely. In most of them (35 cases), ise yalnız behaves like ise sadecelyalnızca sharing the same function. Because yalnız has meanings and functions like alone/lonely, but or only, in concordance lines, whatever feature or collocational pattern we focussed on, we have so far found it tiring and hard to pick out lines where yalniz means and behaves like only as the unique sense in which it has synonymy relation with the other adverbials sadece and yalnizca. However, in the collocation pattern ise yalniz, oddly enough, this adverbial mostly has the sense only; therefore, it 
seems reasonable to say "ise" tends to force yalnız to mean only when they are together. One example is given below:

(73) (Bir balık türü) Akdeniz ve Ege'de y1l boyunca, Karadeniz'de (XP) ise yalnız yaz ayları görülür. [It (a fish species) is found in the Mediterranean and Agean seas all year long, whereas in the Black Sea (XP) it is seen only in summer months] (W-SI22C3A-4728-17).

It can be concluded that in the phraseology XP ise sadece, the adverb sadece is intersubstitutable with yalnızca and yalnız (though rare with yalnız). Such conventional, pre-constructed phrases are the result of the brain's repeated exposure to them over time, which forms linguistic schemas (Partington 1998:23). In fact the linguistic schema "XP ise sadece / yalnızca / yalnız" constitutes a part of a larger schema, a semantic one. Stubbs (2002:96) defines such a semantic schema as "clusters of lexis (node and collocates), grammar (colligation), semantics (preferences for words from particular fields) and pragmatics (connotations or discourse prosodies)" The semantic schema activated by this phraseology is "stored as a whole and becomes a model for production" (Partington, 1998:23). The representation of XP ise sadece / yalnızca / yalnız in Turkish speakers' mental lexicon is as follows:

Figure 1. Linguistic schema motivating the use of the pattern ise sadece / yalnızca / yalnız

First mention some entities of contrast;

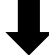

Then mention the entity (XP) to be highlighted, locating it before ise;

Next place sadece, yalnızca or yalnız;

Finally mention a distinctive feature or fact about the XP.

From Figure 1 and the preceding coverage of the co-occurrence pattern ise + adverbial, it is clear that sadece, yalnızca and yalnız are interchangeable in the phrase ise + adverbial. The difference lies in the frequency, with "ise sadece" being the most frequent, "ise yalniz" being by far the most infrequent and "ise yalnızca" somewhere between them as can be seen below in Table 7. 
Table 7. The co-occurrence frequency of "ise" at-N1 with sadece, yalnizca and yalnuz on the basis of data from TNC 23.0

\begin{tabular}{lll}
\hline Lexical Bundle & Number of Occurrence & Frequency in One Million \\
\hline ise sadece & 558 & 11,24 \\
ise yalnizca & 159 & 3,2 \\
ise yalnız & 48 & 0,97 \\
\hline
\end{tabular}

The collocational strength between ise and sadece is the strongest and the one between ise and yalnız is the weakest. However, as we said before, it is odd that when yalniz colligates with ise (as for or whereas), it tends to be used in the sense of only despite its other meanings like alone, lonely or but.

\subsection{Semantic Preference}

As part of the Model of Extended Lexical Units (Stubbs 2002), a node under examination is also evaluated in terms of their semantic preferences which usually become clear from the typical collocates. However, in our case, as exclusive adverbials, sadece and yalnızca modify various phrases and clauses with no distinct semantic preferences. Their largely overlapping top collocates lists (Appendix 1 and 2) reveal that most of the collocates are grammatical collocates, that is, colligates (ama, ise, değil, için, olarak) or both collocates and colligates (pronouns, bu, o, ben, kendi; quantifiers bir, iki, birkaç). To some extent, it can be said that sadece and yalnızca have semantic preferences for singular pronouns, and quantifiers.

As for yalnız, it behaves like sadece and yalnızca when it means only. On the other hand, yalniz also means alone/lonely and but. In the sense of alone/lonely, yalnız has a semantic preference for words or phrases from the domain of loss or separation (i.e. yalnız ol- = be alone/lonely; yalnız kal-= become lonely/alone; yalnız bırak- = leave/keep someone alone). When yalnız functions like but, yalniz has semantic preferences for the domains of importance, warning, requirement and focussing attention (dikkat edeceğimiz önemli bir nokta= one important point to take into consideration; ilginç bir fark var = there is an interesting difference; dikkati çekiyordu= it attracted attention; burada küçük bir ayrıntı var = there is a small detail to mention here; Hasan'ın garip bir huyu vardır = Hasan has a strange habit; önemli bir kusuru var $=\mathrm{x}$ has a significant defect; ne hikmetse = heaven knows why, etc.).

\subsection{Semantic/Discourse Prosody}

As we stated in theoretical framework section, prosody is the most important aspect of word selection. It is the junction of form and function and it is the reason why it is chosen among other similar words depending on its pragmatic 
function which can be determined from its concordance. As exclusive adverbials meaning only, sadece, yalnızca and yalnız have neutral prosodies because the words or phrases modified by them can have positive or negative connotations. In other meanings of yalnız, we directly feel a negative prosody. Different prosodies are felt when these words form lexical bundles like ben sadece / yalnızca (ben yalnız is very rare in this function), artık sadece / yalnızca / yalnız, XP ise sadece / yalnızca / yalnız, ama sadece / yalnızca / yalniz.

The lexical bundle ben sadece / yalnizca has an unfavourable prosody of self-defence. In some examples, this lexical partnership has the discourse prosody of modesty. These prosodies can be associated with neither "ben" (I) nor "sadece / yalnizca" in the collocational pattern, but they are prosodies of the whole pattern. That is similar to the prosody of difficulty postulated for the lexical bundle "the naked eye" (Sinclair, 1996/2004). Likewise, neither the word "naked" nor "eye" has the prosody of difficulty, but the combinatorial meaning of the idiomatic expression does. To sum up, while sadece and yalnızca have neutral prosodies, their lexical patterning with "ben" at -N1 position causes them to have the negative prosody of self-defense to clarify one's misunderstood stance in an awkward position. Ben yalnız is too rare a pattern to consider in this regard. Sample concordance lines for ben sadece/yalnızca:

(74) "Kim ötekiler? Kime gidip, ne söyleyeyim? Ben sadece kendime karş1 sorumluyum. [Who are the others? Who am I supoosed to go and say what? I am just responsible to myself] (self-defense in desperation) (WHE09C3A-0579-5)

(75) Ben seni yenmek istemiyorum ki. Bunu hiçbir zaman istemedim. Ben sadece senin hayatında olmak istedim. (correct a misunderstanding about one's purpose) (I do not want to defeat you. I have never wanted that. I only/just wanted to be in your life) (W-NA16B1A-0322-48)

(76) KADIN: Siz de alınganlık yapmak için firsat kolluyorsunuz! Ben yalnızca, olabilecek bir şeyden söz ediyordum. ADAM: Başka neler olabilir?(clarifying a misunderstanding, self-justification) (LADY: You seem to be so ready to be susceptible to anything I say! I was only/just talking about something that might happen. MAN: What else may happen?) (W-TA14B1A-1591-53)

The lexical bundle ama sadece / yalnızca / yalnız (yalnız is too rare again) has a negative prosody. Sadece and yalnızca's colligation with the adversative conjunction "ama" (but) form this lexical partnership, which connotes a striking contradiction or concession about a point expressed before the pattern. After this phraseology the truthfulness or applicability of an idea or a claim is 
extremely restricted. First a point or claim is made and then it is strikingly restricted with the exclusive adverbials. Sample lines:

(77) Şikayet edilen videoyu kaldırıyor, ama sadece Türkiye'den kaldırıyor. [It is blocking the video complained about, but only removing it from (internet sites) in Turkey] (W-WI45E1D-4775-109)

(78) Bir çok söz verdiler, ama yalnızca bir tanesini tuttutlar. [They made several promises, but they kept only one of them] (W-LA16B4A-0289109)

In the lexical bundle artık sadece / yalnızca / yalnız (yalnız is too rare again), artık means now as compared to the past facts or habits. Artık itself indicates a change in one's situation between the past and the present and can have positive or negative connotations. Hence it has a neutral prosody depending on whether the new situation marked by artık is good or bad. However, the lexical bundle artık sadece / yalnızca / yalnız on which we focus connotes a big change in one's state or situation, which may be positive or negative. If there is a big change for the better, this collocational pattern has the prosody of big satisfaction; if the big change is for the worse, the expression has the prosodic function of implying big dissatisfaction. In conclusion, the speaker's pragmatic motivation behind their selection of this phrase is to express a big change in their situation from past to present.

The lexical bundle ise sadece / yalnızca / yalnız (yalnız is too rare again) is a colligational pattern which has more negative connotations than positive about someone or something focussed and compared with other things or people already mentioned before the phrase. The pattern profiles how restricted a situation someone or something is in as opposed to the previously mentioned other people or things. "Ise" focusses on something or someone (XP) and the adjacent sadece or yalnizca points to an exclusively limited or restricted feature of the XP.

Because semantic/discourse prosody is an abstraction that is usually made from the whole concordance of a lexical item and cannot be determined from individual lines, the sample lines mentioned above in this part are just a few examples to give an insight.

\subsection{Summary of the Results Obtained from the Research}

a) Sadece is the most typical of the exclusive adverbials which correspond to only/just in English. Sadece is almost three times as frequent as the other adverbials in the corpus. Given that yalnız has several senses and functions and Table 8 shows its total occurrences, the real number of cases where it 
functions as an exclusive adverbial is much smaller than it seems in the table.

Table 8. Frequency data for the adverbials (written part of the corpus TNC

\begin{tabular}{lll}
\multicolumn{2}{c}{ v3.0) } \\
\hline Adverbial & $\begin{array}{l}\text { Number of occurrence in } \\
\text { TNC v3.0 }\end{array}$ & $\begin{array}{l}\text { Frequency in one million } \\
\text { words }\end{array}$ \\
\hline Sadece & 40543 & 816.34 \\
Yalnızca & 13492 & 271.66 \\
Yalniz $^{4}$ & 14607 & 294.12 \\
\hline
\end{tabular}

b) All the three adverbials are used as paired conjunctions (sadece/yalnızca/yalnız ....değil (aynı zamanda, optional) .... de/da," which corresponds to the English paired conjunction "not only .... but also ....").

c) All the adverbials can be duplicated with " $v e$ " (and) in the middle of the phrase (node ve node). The phraseologies sadece ve sadece, yalnizca ve yalnızca and yalniz ve yalnız are more emphatic, thus adding to each adverbial's exclusive or partitive power.

d) Sadece and yalnızca are sometimes used at sentence/utterance final position and can have summative or clarifying functions. This anaphoric use of the adverbials is like a pragmatic full stop at the end of a sentence, implying how the topic/issue under consideration can be ultimately summarised and that there is no other thing to mention better or more concise (nothing but simply... function).

The sentence final potsmodifier function of sadece and yalnuzca sometimes has the additional benefit of disambiguation. Because Turkish is a head-last language in terms of noun, verb or prepositional phrases, placing the exclusive adverbial at final position just after the head of a phrase can enable them to modify the whole phrase rather than possibly modifying other words in the constituents of the phrase (if the adverbial is put before the phrase).

e) Yalnız is polysemous and has distinct pragmatic features. In the sense of only, yalnız behaves like sadece and yalnızca with a partial sense synonymy relation. In many concordance lines, we observed that it means alone or

4 The results for yalnız in Table 8 are deceptive because yalnız is polysemous and multifunctional. Only when it is used in the sense of only/just does it have a synonymy relationship with sadece and yalnizca. In many cases in its concordance it means alone/lonely or but (ancak) and can sometimes be used as a discourse particle (topic shifter). Therefore, its accurate frequency results can only be achieved if the cases where it means only are counted, which is very difficult for 14607 lines. In short, in the sense of only, sadece is the most frequent, yalnizca is the second most frequent and yalniz is the least frequent. 
lonely. In some cases it behaves like Turkish adversative connective ancak (but) with pragmatic functions of marking a warning, reminding, requirement or exception. We also observed yalnız as a discourse particle signalling a topic shift.

f) Sadece and yalnizca's top 15 co-occurences (collocates/colligates) proved to be almost overlapping with 12 words being the same. This is an indication of a high intersubstitutability of these adverbials. In contrast, as a polysmeous word, yalniz's top 15 co-occurrence list is quite different.

g) Sadece and yalnizca often co-occur with the adversative connective ama (but), artık (now as compared to a past situation), yok (non-existent), ben (I) and the discourse connective ise (functioning as as for or whereas). The high lexical priming between sadece/yalnizca and these words proved to be motivated by pragmatic concerns such as introducing a big restriction about a previously expressed point, a big change in one's situation from past to present, bringing a concept's content or meaning into question, expressing self-justification and display of modesty, like depreciatory meaning of just (Lee, 1987). While sadece and yalnızca are interchangeable in such contexts, yalniz was found to be rarely used. It was observed that even if yalniz is used in these co-occurrence patterns, many examples carry its other meanings. Oddly enough, in the majority of cases in which yalnız colligates with ise, yalnız just means only.

h) Yalnız has pragmatic functions of its own. It can mark a requirement to be imposed on the addressee, function as a reminder, mark a warning and have a topic shifter function.

i) In the sense of only, the three exclusive adverbials in our synonym set do not have item-specific semantic preferences; that is, they can have collocates from any domain. They are just focus adverbials modifying various phrases whose lexical constituents do not require certain semantic domains. When yalniz means alone or lonely, it naturally has a semantic preference for domains of loss, separation or sadness. When yalnız functions like but (ancak), it has semantic preferences for domains of importance, warning or requirement.

j) The adverbials sadece, yalnizca and yalnız have neutral prosodies as long as they mean only. Yalniz, when it means alone/lonely or but (ancak), has a negative prosody. We also attempted to postulate prosodies for collocational/colligational patterns involving these adverbials. It is clear that a node's certain co-occurrence patterns become lexical bundles whose further collocates might change which would indicate different prosodies (Aksan, Y. 2018; Adigüzel, 2018). In this connection, the prefab "ben sadece" and "ben yalnizca" have a negative prosody of self-defence or a prosody of displaying modesty or apology. "Ama sadecelyalnızca/yalnız" (but only) has negative prosodies of introducing a striking exception or 
limitation to a point already made. A Turkish speaker using "artık sadece, yalnızca, yalnız" (now only) is pragmatically motivated to convey a big yet restricted change (not a complete change) in a situation or in their own situation from past to present. The lexical bundle "ise sadece/yalnızca/yalniz" tends to have unfavourable connotations and is a double focuser to assert how exclusively different or limited something or someone is as compared to other things or people already mentioned before these lexical units.

\section{How Synoymous Sadece, Yalnızca and Yalnız Are}

Hunston (2002) suggests that one of the main benefits of concordance lines is that they help us interpret "the meaning and behaviour of individual lexical items, and the pragmatic meaning of given phrases" (Hunston, 2002:39). He also states that "words with similar meanings tend to share patterns" (ibid. p.48). It is for this reason that we not only checked the TNC v3.0 for any distinct senses of sadece, yalnızca and yalnız but also focused on their collocational patterns and phraseologies. We not only searched for semantic and pragmatic similarities but also collocational overlaps as indicative of the intersubstitutability of these Turkish focus adverbs.

Parktington (1998:50) cites Halliday (1992) to define meaning. In their views, meaning is function in context; similarly "equivalence of meaning (synonymy) is therefore equivalence of function in context." It is for this reason that we based our research into senses and functions of the adverbs sadece, yalnızca and yalnız on attested data from the TNC v3.0 and looked deeper into expanded texts surrounding concordance lines to get clearer semantic and pragmatic pictures of the words and their collocation patterns. Interpreting a large bulk of concordance lines for distinct senses of these focus adverbs and their collocational and colligational behaviour, we were able to make judgements about how synonymous and intersubstitutable they are.

There are various definitions and classifications of synonymy. Given Murphy's (2003) classification, sadece, yalnizca and yalniz in the sense of only are logical synonyms. Murphy's subclassification "full synonyms" is appropriate for sadece and yalnızca because "their lexical and semantic representations are the same, which results in their being used in the same ways" (Murphy, 2003:147). Another subclassification for logical synonyms is "sense synonyms", which is appropriate for yalnız's synonymy relation with the other exclusive adverbials because yalnız is polysemous and pragmatically multifunctional, so only in its meaning of only is yalniz synonymous with sadece and yalnızca.

If we interpret our corpus findings in Lyons' terms (1981), sadece and yalnızca can be classified as "complete synonyms" because their meanings and 
other properties match, with the only seeming difference being the higher frequency of sadece. Although yalniz, in the sense of only, seems to be synonymous with sadece and yalnizca, it is much further away from being a complete synonym because some collocational, colligational and pragmatic findings associated with sadece and yalnizca are either inapplicable or highly marginally applicable to yalnız.

In Cruse's terms (1986) sadece, yalnızca and yalnız are cognitive synonyms which are interchangeable in contexts where they mean only. Sadece and yalnızca, having only one denotational meaning as an exclusive adverbial, are indisputably "cognitive synonyms" because they are fully intersubstitutable in the concordance lines we exhaustively analysed. Yalnız is cognitively synonymous with the other adverbs as long as it means only. Hence, it has a "sense synonymy" relation with the others. Sadece and yalnizca have 12 collocational overlaps in their top 15 collocational lists, but this is not the case for yalnız. However, despite co-occurrence differences, sets of items can be accepted as cognitive synonyms (Cruse, 1986:279). The striking overlap between sadece and yalnizca's top co-occurrence lists indicates that they have got a much higher intersubstitutability.

Another noteworthy point is that a similarity in form does not mean a higher degree of synonymy. "For example, end and ending are rather similar in form, but end is not necessarily considered to be a better synonym for ending than a word with a less similar form, like conclusion" (Murphy, 2003:140). Likewise, yalnız and yalnızca (derived from yalnız with the suffix-cA) look more similar in form compared to sadece, but yalnizca is much more synonymous with sadece than yalnız. While collocational, colligational and pragmatic features of sadece and yalnizca overlap, and thus are interchangeable, they are substitutable with yalnız in certain contexts. That is especially because yalnız has different meanings and pragmatic functions, which motivates it to have a rather different lexical profile. On the other hand, when it behaves like only, the gap between yalnız and the other adverbials gets narrower, though not completely bridged. Although we observed from the corpus data that sadece and yalnizca have equinormality in their semantic contents and pragmatic functions (with yalnızca being used less frequently), yalnız turned out to have marginal tendencies to share contextual equivalences with the other adverbials even in the sense of only - the only sense with respect to which it is cognitively synonymous with sadece and yalnizca. 


\section{Conclusion}

Hoey $(2005: 11)$ states “...the mind has a mental concordance of every word it has encountered, a concordance that has been richly glossed for social, physical, discoursal, generic and interpersonal context" and implies that an individual updates the mental concordance of a word as he/she encounters new uses or functions. Then the concordances of sadece, yalnizca and yalnız which we obtained from the TNC v3.0 reflect mental concordances of the Turkish speech community or mental models of extended lexico-semantic units (Stubbs, 2002:96) in our language community. The corpus-driven study based on TNC v3.0 has identified lexical profiles of the synonym set of Turkish exclusive adverbials sadece, yalnizca and yalniz. Semantic and pragmatic features as well as collocational and colligational properties of the adverbials were identified. The study demonstrated that sadece and yalnizca have contextual and cooccurrence equinormality and complete synonyms in Lyons' (1981) terms, full synoyms in Murphy's (2003) terms and congnitive synonyms in Cruse's (1986) terms. The adverbial yalniz is polysemous and pragmatically multifunctional and it has a partial synonymy relation with the other adverbials only when it means only. Yalnzz was also found to have a topic shifter function. The study revealed that while the three adverbials have neutral prosodies in the sense of only, when they form lexical bundles such as ben sadecelyalnizca, ama sadece/yalnizca, negative prosodies emerge. All the detailed conclusions made from the study are presented in detail under the heading 4.6 above.

\section{References}

Adigüzel, F. (2018). Corpus-driven lexical profiles of Turkish fear verbs and metaphorical profiles of somatic fear idioms in Turkish (Unpublished Doctoral Dissertation), Mersin University, Mersin.

Aksan, Y., Duran, N., Ersen, D., Hızarcı, Ç., Korkmaz, S., Sever, B. \& Sezer, T. (2008). Türkçede yakın anlamlı sözcükler: Bir derlem çalışması. 22. Ulusal Dilbilim Kurultayı Bildirileri, Van. 558-567

Aksan, D. (1972). Eşanlamlılık sorunu ve Türk yazı dilinin eskiliğinin saptanmasında eşanlamlılardan yararlanma. Türk Dili Bilimsel Kurultayı. 27-29 September, Ankara.

Aksan, Y. (2011). Derlem temelli sözcük anlambilimi çalışmalarının Türkçenin eğitimine katkısı. Türkçenin eğitimi-ögretiminde kuramsal ve uygulamalı araştırmalar. Die Blaue Eule, Esen.

Aksan, Y. (2018). Küsmek, darılmak, gücenmek: Derlem çıkışlı sözcük profilleri. In Aksan, Y. \& Aksan, M. (Eds), Türkçede yapı ve işlev (pp.1-30). Ankara: BilgeSu Yayıncilik.

Baker, R., Hardie, A. \& McEnery, T. (2006). A glossary of corpus linguistics. Edinburgh: Edinburgh University Press.

Bednarek, M. (2008). Semantic preference and semantic prosody re-examined. Corpus Linguistics and Linguistic Theory, 4 (2), 119-39. 
Cruse, D. A. (1986). Lexical semantics. CUP, Cambridge.

Cruse, D. A. (2000). Meaning in language: an introduction to semantics and pragmatics, OUP, Oxford.

Divjak, D. (2010). Structuring the Lexicon: A Clustered Model for Near Synonymy. Berlin: Mouton de Gruyter

Doğan, N. (2011). Türkiye Türkçesi fiillerinde eş anlamlılık.” Uluslararası Sosyal Araştırmalar Dergisi. 4 (19), 78-88.

Edmonds, P. and Hirst, G. (2002). Near synonyms and lexical choice. Computational Linguistics, 28 (2), 105-144.

Ersoylu, H. (2011). Eş anlamlılık mı, yabancı kaynaklı karşılık oluş mu? Türk Dili, Mart, TDK Yay. Ankara, 250-256.

Firth, J., R. (1957). Modes of meaning. Papers in Linguistics, Oxford: Oxford University Press.

Göksel, A., \& Kerslake, C. (2005). Turkish: A comprehensive grammar. Routledge.

Gries, St. Th., \& Otani, N. (2010). Behavioral profiles: A corpus-based perspective on synonymy and antonymy. ICAME Journal, 34, 121-150.

Hoey,M. (2005). Lexical Priming: a new theory of words and language. London and New York: Routledge.

Hunston, S. (2002). Corpora in Applied Linguistics. Cambridge: CUP.

Lee, D. (1987). The semantics of just. Journal of Pragmatics, 11, 377-398.

Leech, G.N. (1985). Semantics. The study of meaning. Hamnondsworth, Penguin.

Louw, B. (2000). Contextual Prosodic Theory: bringing semantic prosodies to life. In Chris Heffer \& Helen Sauntson (Eds.), Words in context. In honour of John Sinclair (pp.48-94). Birmingham: ELR.

Lyons, J. (1981). Language and linguistics. Cambridge: Cambridge University Press.

McEnery, T., \& Hardie A. (2012). Corpus Linguistics. Cambridge.

Murphy, M.L. (2003). Semantic relations and the lexicon. Cambridge: CUP.

Partington, A. (1998). Patterns and Meanings. Amsterdam: John Benjamins.

Partington, A. (2004). Utterly content in each other's company. International Journal of Linguistics, 9(1), 131-156.

Sinclair, J. (1991). Corpus, concordance, collocation. Oxford: Oxford University Press.

Sinclair, J. (1996/2004). Trust the text. Language, corpus and discourse. London: Routledge.

Sinclair, J. (1998). The lexical item. In E. Weigand (Ed.), Contrastive Lexical Semantics (pp.1-24). Amsterdam: Benjamins.

Sinclair, J. (2000). Lexical Grammar. Darbai in dieonos 24: 191-204.

Sinclair, J. (2003). Reading Concordances. London: Longman.

Sinclair, J. M. (2004). Trust the Text. London: Routledge.

Stanojević, M. (2009). Cognitive Synonymy: A general overview. Linguistics and literature, 7 (2), 193-200.

Stubbs, M. (2002). Words and phrases: Corpus Studies of Lexical Semantics. Oxford: Blackwell Publishers.

Steward, D. (2010). Semantic Prosody: A Critical Evaluation. London, Routledge.

Tognini-Bonelli, E. (2001). Corpus Linguistics at Work. Amsterdam: John Benjamins.

Vardar, B. (1998). Açıklamalı dilbilim terimleri sözlüğ̈̈̈. İstanbul: ABC Yayınları. 


\section{Appendices $^{5}$}

Appendix 1. Top Collocates List for Sadece $(-2+2$ span)

\begin{tabular}{lllll}
\hline Collocates & $\begin{array}{l}\text { Total number in } \\
\text { written texts }\end{array}$ & $\begin{array}{l}\text { Expected } \\
\text { collocation } \\
\text { frequency }\end{array}$ & $\begin{array}{l}\text { Observed } \\
\text { collocation }\end{array}$ & $\begin{array}{l}\text { Log-likelihood } \\
\text { value }\end{array}$ \\
\hline değil & 79231 & 64,6797 & 2390 & 12808,5587 \\
bir & 1315029 & 1073,5147 & 4716 & 7031,9845 \\
bu & 693877 & 566,4416 & 2916 & 5006,1276 \\
ve & 1128733 & 921,4332 & 3436 & 4184,1466 \\
sadece & 40543 & 33,097 & 690 & 2899,0272 \\
için & 280508 & 228,9907 & 1174 & 1973,3004 \\
ise & 94334 & 77,0089 & 678 & 1760,4424 \\
ben & 93876 & 76,635 & 626 & 1541,563 \\
O & 183423 & 149,7361 & 814 & 1441,2199 \\
kendi & 66771 & 54,508 & 485 & 1266,6238 \\
birkaç & 21528 & 17,5742 & 301 & 1148,9752 \\
ama & 142833 & 116,6007 & 616 & 1059,8044 \\
olarak & 216437 & 176,6868 & 731 & 976,5395 \\
İki & 90454 & 73,8415 & 475 & 971,7836 \\
yok & 52374 & 42,7551 & 368 & 938,4658 \\
\hline
\end{tabular}

Appendix 2. Top Collocates List for Yalnuzca (-2+2 span)

\begin{tabular}{lllll}
\hline Collocates & $\begin{array}{l}\text { Total number in } \\
\text { written texts }\end{array}$ & $\begin{array}{l}\text { Expected } \\
\text { collocation } \\
\text { frequency }\end{array}$ & $\begin{array}{l}\text { Observed } \\
\text { collocation }\end{array}$ & $\begin{array}{l}\text { Log-likelihood } \\
\text { value }\end{array}$ \\
\hline değil & 79231 & 21,5243 & 665 & 3312,2449 \\
bir & 1315029 & 357,2469 & 1804 & 3116,2407 \\
bu & 693877 & 188,5018 & 1021 & 1839,0511 \\
ve & 1128733 & 306,6368 & 1022 & 1069,9458 \\
için & 280508 & 76,2041 & 394 & 666,992 \\
kendi & 66771 & 18,1393 & 209 & 643,2395 \\
O & 183423 & 49,8295 & 284 & 524,5907
\end{tabular}

5 Bold words indicate the overlapping collocates / colligates of sadece and yalnizca. 


\begin{tabular}{lllll}
\hline Collocates & $\begin{array}{l}\text { Total number in } \\
\text { written texts }\end{array}$ & $\begin{array}{l}\text { Expected } \\
\text { collocation } \\
\text { frequency }\end{array}$ & $\begin{array}{l}\text { Observed } \\
\text { collocation }\end{array}$ & $\begin{array}{l}\text { Log-likelihood } \\
\text { value }\end{array}$ \\
\hline yalnızca & 13492 & 3,6653 & 94 & 430,4878 \\
ise & 94334 & 25,6272 & 185 & 414,7975 \\
artık & 43877 & 11,9198 & 130 & 386,4215 \\
birkaç & 21528 & 5,8484 & 101 & 386,2797 \\
ama & 142833 & 38,8027 & 211 & 372,6289 \\
değildir & 24145 & 6,5593 & 92 & 315,8894 \\
ben & 93876 & 25,5028 & 158 & 312,8241 \\
iki & 90454 & 24,5732 & 153 & 304,1655 \\
\hline
\end{tabular}

